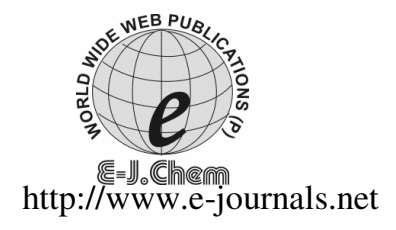

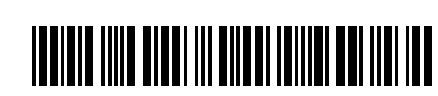

ISSN: 0973-4945; CODEN ECJHAO

E-Journal of Chemistry 2012, 9(1), 451-464

\title{
Industrial Potential of Two Varieties of Cocoyam in Bread Making
}

\author{
NNABUK O. EDDY*, EMMANUEL ESSIEN ${ }^{\S}$ \\ ENO E. EBENSO ${ }^{\#}$ and RICHARD A. UKPE \\ * Department of Chemistry, Ahmadu Bello University, Zaria, Nigeria \\ ${ }^{\S}$ Department of Chemistry, University of Uyo, Nigeria \\ \#Department of Chemistry, North West University (Mafikeng Campus) \\ Private Bag X2046, Mmabatho 2735, South Africa \\ Department of Chemistry \\ Michael Okpara University of Agriculture, Umudike, Nigeria \\ nabukeddy@yahoo.com
}

Received 3 March 2011; Revised 8 June 2011, Accepted 2 July 2011

\begin{abstract}
The evaluation of the chemical (proximate composition, mineral composition, toxicant composition and vitamin composition), nutritional and industrial potentials of two varieties of cocoyam (Xanthosoma sagittifolium (XS) and Colocasia esculenta $(C E)$ ) were carried out using recommended methods of analysis. Baking trials were conducted with the two varieties of cocoyam at different levels of substitution $(20 \%, 30 \%$ and $50 \%)$. The produced bread samples were analyzed for their physical parameters and proximate composition. Sensory evaluation test was also carried out on the produced bread. The result of the analysis showed that the preferred bread in terms of loaf weight, volume and specific volume was given by sample I (control sample) containing $100 \%$ wheat flour with a specific volume of $3.54 \mathrm{~cm}^{3} / \mathrm{g}$. This was closely followed by sample A with specific volume of $3.25 \mathrm{~cm}^{3} / \mathrm{g}$ containing $20 \%$ substitution level of $C E$. Sample H containing 50\% substitution level of $X S$ with specific volume of $2.58 \mathrm{~cm}^{3} / \mathrm{g}$ gave the poorest performance. The sensory evaluation result further revealed that apart from the $100 \%$ wheat flour based sample I, sample D with $20 \%$ substitution level of $X S$ was rated good and maintained better performance amongst the cocoyam varieties while samples $\mathrm{G}$ and $\mathrm{C}$ with $100 \%$ and $50 \%$ substitution level of $C E$ respectively were rated the poorest. The proximate composition of the bread samples was also carried out. $C E, X S$ and wheat bread samples $(100 \%)$ recorded $15.0633 \pm 1.4531,12.1133 \pm 1.5975$ and $11.2867 \pm 0.7978$ respectively for the moisture content. $X S$ bread recorded the highest carbohydrate content of $45.0133 \pm 3.0274$. In terms of ash, $C E$ bread recorded the highest value of 31.4367 \pm 1.6159 while wheat bread recorded the highest value for protein i.e. 20.6033 \pm 0.8113. XS performed better in terms of crude fat and energy value of $12.2967 \pm$ 0.8914 and 371.5367 respectively. The use of cocoyam - wheat flour mixture in producing composite bread is therefore strongly recommended from this study.
\end{abstract}

Keywords: Cocoyam, Nutritional, Industrial potentials, Bread 


\section{Introduction}

Food nutrients include carbohydrate, lipids, proteins, minerals, vitamins and water. Although food may be derived from plant and animals, plant is the only living organism that is capable of carrying out photosynthesis and is the major source of food in nature's chain ${ }^{1}$. Food of plant origin may be classified into cereals, roots and tubers, sugars and syrups, legumes, pulses, nuts and oil seeds, vegetables and fruits ${ }^{2}$. Roots and tubers used as food include yams, cassava, potatoes, sweet potatoes and cocoyam ${ }^{3}$. Roots and tubers have a high moisture content resulting in short storage life under ambient conditions and because of these, they are highly perishable and huge losses can occur after harvest ${ }^{4,5}$. Roots and tubers contribute about $20-48 \%$ of the total calories and about $7.1 \%$ protein to the diets of the people of sub-Saharan Africa. In Nigeria, they are the main sources of calories accounting for over $50 \%$ of the caloric intake of the people of the south. Yam has less than $6 \%$ protein while cassava is a poor source of protein, less than 3\%. Cocoyam is fair in protein, 7-9\% and calcium. Sweet potatoes are poor in protein but fair in their supply of the $\beta$-vitamins. Therefore, cocoyam has some nutritional advantages over the other root and tubers crops.

The most popular and widely consumed species of cocoyam are the Colocasia, xanthosoma, alocasia, caryotosperma chamissonis and the amophophallus Campanulatus and their chemical constituents vary with varieties ${ }^{6}$. Cocoyams are rich in moisture content with highest values of $75.4 \%{ }^{6}$ while observing values of $69.1 \%$ and $67.1 \%$ for Colocasia esculenta and xanthosoma sagittifolium. The crude protein content for C.esculenta is about $2.1 \%{ }^{6,7}$. The fat content for C. esculenta ranges between $0.1 \%-0.3 \%{ }^{6-8}$. The ash content for C.esculenta falls within the range of $0.80 \%-1.1 \%{ }^{8}$. Total oxalate in C.esculenta is estimated at $65 \mathrm{mg} / 100 \mathrm{~g}$ and the hydrocyanic acid and phytic acid values of $1.04 \pm 0.06 \mathrm{mg} / 100 \mathrm{~g}$ and $40.9 \pm 2.9 \mathrm{mg} / 100 \mathrm{~g}$ respectively ${ }^{1}$.

The vitamin A content of cocoyam is very low ranging from $0.007 \mathrm{mg} / 100 \mathrm{~g}$ to $0.02 \mathrm{mg} / 100 \mathrm{~g}^{6,7,9}$. Also, cocoyam is fairly high in crude and true proteins, rich in ash, low in fiber and is not a fair source of oils and fats. Cocoyam is also rich in some micro elements including $\mathrm{P}, \mathrm{Mg}, \mathrm{Zn}$, etc. Cocoyam is fairly rich in carotene, ascorbic acid, thiamin, riboflavin and nicotinic acid.

Considering the nutritional quality of cocoyam, the high starch content and it quality (i.e. fine starch grains), the level of utilization of cocoyam and its products both domestically and industrially is quite low. People and industrialists seem to be ignorant of the nutritional and industrial potential of cocoyam. Investigating the nutritional quality of cocoyam and creating awareness on the nutritive quality and possible industrial potential would increase the utilization of cocoyam and its products domestically and industrially. In spite of the high nutritional value of cocoyam, the rate at which most Nigerians consume cocoyam is still low when compared to other root and tubers crops. The notion that cocoyam is a "poor man" food has been established in most Nigerian homes such that some are not comfortable to be found in the practice of consuming cocoyam. Malnutrition in Nigeria and other developing nations is traced to the consumption of low quality and quantity of food ${ }^{9}$.

Most importantly, because the number of reported cases of diabetes is on the high side the price of diabetes diets (such as wheat bread and plantain flour) are also high. Bread is a preferred meal in most cities. If a diabetic patient must consume bread, it has to be $100 \%$ wheat bread. In recent times, efforts has been made by the federal government of Nigeria (through its agencies such as raw materials development and research institute) toward the development of composite bread using a mixture of wheat flour and cassava flour. These 
have become an acceptable practice. However, literature is scanty on the production of composite bread from cocoyam and on the chemical composition of such breads. The present research is aimed at investigating the industrial potential of cocoyam in bread making.

\section{Experimental}

The two species of cocoyam (Xanthosoma sagittifolium and Colocasia esculenta) used for this work were obtained from a farm locally and were identified in the National Root Crops Research Institute (N.R.C.R.I), Umudike, Nigeria. Samples for determination of wet analysis (moisture content) were used immediately after harvest while those for dry weight analysis were washed, peeled, sliced and allowed to dry in the sun for ninety six hours till they became brittle. They were then crushed to powder using Moulinex blender, stored in air-tight bottles labeled and kept in a cool dry place. De-ionized water was used wherever applicable. The ground samples comprised whole corms and cormels in fairly equal proportions.

\section{Determination of moisture content ${ }^{10}$}

$5 \mathrm{~g}$ of Each of the samples were weighed and dried at about $105{ }^{\circ} \mathrm{C}$ in a hot air circulating oven for six hours to constant weight. The moisture content was reported as percentage loss in weight expressed in terms of wet weight.

$$
\% \text { Moisture }=\frac{\text { loss in weight of sample }}{\text { Weight of original sample }} \times 100
$$

Determination of ash content ${ }^{10}$

The ash content was determined by igniting $10 \mathrm{~g}$ of dry sample in a muffle furnace at about $550{ }^{\circ} \mathrm{C}$ to constant weight. It was cooled in a dessicator and weighed. The ash content was reported as a percentage dry mass.

$$
\% \text { Dry mass }=\frac{\text { mass of ash }}{\text { mass of oven dried sample }} \times 100
$$

Determination of crude protein ${ }^{10}$

$5 \mathrm{~g}$ of Dry sample were weighed and digested in macro-Kjeldahl apparatus with concentrated sulphuric acid. The ammonia liberated from the resulting ammonium sulphate after adding sodium hydroxide was distilled into $1 \mathrm{M}$ boric acid and then titrated with $0.1 \mathrm{M}$ $\mathrm{HCl}$. The nitrogen value estimated was multiplied by 6.25 (protein factor) to obtain the value of the crude protein, expressed as the percentage of dry sample mass.

$$
\% \text { Nitrogen }=\frac{1.40 \times \mathrm{T}}{\text { Weight of sample in grams }} \times 100
$$

Where $\mathrm{T}$ is the titre value and $1 \mathrm{~mL}$ of $0.1 \mathrm{M} \mathrm{HCl}=1.4 \mathrm{~g}$.

\section{Determination of fat $^{10}$}

The crude fat was extracted from $5 \mathrm{~g}$ of each sample using a solvent extraction apparatus (Soxhlet apparatus) with low boiling point petroleum ether (b.p $40-60{ }^{\circ} \mathrm{C}$ ) as solvent. The weight of the lipid obtained after evaporating off the solvent from the extract gave the weight of the lipid present in the sample.

$$
\% \text { Crude fat }=\frac{\text { weight of extract }}{\text { weight of dry sample }} \times 100
$$




\section{Determination of crude fibre $e^{10}$}

$5 \mathrm{~g}$ of sample were weighed and exhaustive extraction of substances soluble in $1.25 \%$ boiling sulphuric acid and $1.25 \%$ boiling sodium hydroxide was employed. The residual matter of crude fibre and inorganic material recovered and ash yielded the crude fibre expressed as percentage loss in weight of ashed residue.

$$
\% \text { Fibre content }=\frac{\text { Weight of sample }- \text { Weight of sample after ignition }}{\text { weight of sample used }} \times 100
$$

\section{Estimation of caloric value}

The caloric value of the sample was determined by multiplying the crude protein, lipid and carbohydrate by 4,9 and 4 respectively and then taking the sum of the products.

\section{Determination of mineral element composition}

The analysis was carried out in two stages namely, preparation of ash and stock solutions. In order to prepare the ash solution, $6 \mathrm{~g}$ each of the cocoyam samples were accurately weighed into a previously dried, cooled and weighed crucible. The samples were dried in an oven at $105{ }^{\circ} \mathrm{C}$ after which the samples were introduced into a muffle furnace thermostated at $550{ }^{\circ} \mathrm{C} .5 \mathrm{~mL}$ of Concentrated $\mathrm{HCl}$ (36\% purity) was added to the ashed materials and the content was boiled for $5 \mathrm{~min}$ on a hot plate placed in a fume cupboard. The content was diluted with deionized water and further diluted to the $1000 \mathrm{~cm}^{3}$ mark after re-boiling.

Stock solution of the elements was prepared by diluting the stock solution of their respective salt to the required concentration. These values were used to prepare the calibration curve for the respective element. The absorbance of each of the element was determined by aspirating each of the digested samples into the flame. The values of the absorbance for each of the metals were used to determine the concentration of element through the calibration curve. The $\%$ element in the food was calculated from the formula;

$$
\% \text { Element }=\mathrm{C} / \mathrm{w} \mathrm{v}
$$

$\mathrm{C}=$ concentration of diluted ash solution (from calibration curve), $\mathrm{W}=$ weight of the sample used and $\mathrm{V}=$ value of ash solution diluted.

\section{Determination of sodium and potassium by flame photometry}

About $2 \mathrm{~g}$ of dry samples were digested with $20 \mathrm{~mL}$ acid mixture of $650 \mathrm{~mL} \mathrm{HNO}_{3}, 80 \mathrm{~mL}$ $\mathrm{Hclo}_{4}$ and $20 \mathrm{~mL}$ conc. $\mathrm{H}_{2} \mathrm{SO}_{4}$ and aliquots of the diluted clear digest taken for flame analysis using sodium and potassium filters respectively.

Determination of $\mathrm{Ca}, \mathrm{Fe}, \mathrm{Zn}, \mathrm{Mg}, \mathrm{Mn}, \mathrm{Cd}$, $\mathrm{Ni}$ and $\mathrm{Pb}$, by atomic absorption spectrophotometry

About $2 \mathrm{~g}$ of dry samples were digested with $20 \mathrm{~mL}$ of acid mixture $\left(650 \mathrm{~mL}\right.$ conc. $\mathrm{HNO}_{3}$, $80 \mathrm{~mL} \mathrm{HClO}_{4}$ and $20 \mathrm{~mL}$ conc. $\mathrm{H}_{2} \mathrm{SO}_{4}$ ) and aliquots of the diluted clear digest taken for atomic absorption spectrophotometry using filters that match the different elements.

\section{Determination of vitamin composition}

The vitamin content present in the sample was determined by the A.O.A.C ${ }^{10}$ method as shown below;

Vitamin $C^{10}$

$10 \mathrm{~g}$ of the dry sample was treated with $1 \%$ oxalic acid and $2.0 \mathrm{~mL}$ of $1 \% \mathrm{H}_{2} \mathrm{C}_{2} \mathrm{O}_{4}$ acid and then diluted to $500 \mathrm{~mL}$ using distilled water. 


\section{B.carotene $e^{10}$}

$2.0 \mathrm{~g}$ of the Dry sample were treated with $2 \mathrm{~mL}$ of absolute ethanol and $5 \mathrm{~mL}$ of the heptane was added. Approximate $3 \mathrm{~mL}$ of the heptane layer was transferred to a $10 \mathrm{~mm}$ cuvette and the absorbance in a spectrophotometer (Spectronic 20 model) read against heptane of $450 \mathrm{~nm}$.

\section{Determination of toxicants}

\section{Estimation of Hydrocyanic Acid ${ }^{10}$}

About $10 \mathrm{~g}$ of dry sample were soaked in $250 \mathrm{~mL}$ of distilled water for $4 \mathrm{~h}$ and then steam distilled into $2.5 \%(\mathrm{w} / \mathrm{v}) \mathrm{NaOH}$. About $8 \mathrm{~mL}$ of $6 \mathrm{~N}$ ammonium hydroxide and $2 \mathrm{~mL}$ of $5 \%$ $(\mathrm{w} / \mathrm{v})$ potassium iodide were added to the distillate before titrating with $0.02 \mathrm{~N}$ silver nitrate to a faint permanent turbidity. The $\mathrm{HCN}$ content was estimated by equating $1 \mathrm{~mL}$ of $0.02 \mathrm{~N}$ $\mathrm{AgNO}_{3}$ to $1.08 \mathrm{mg} \mathrm{HCN}$. I mL of $\mathrm{AgNO}_{3}=1.0 \mathrm{mg}$ of $\mathrm{HCN}, 0.65 \mathrm{~mL}$ of $\mathrm{AgNO}_{3}=$ (1.08x0.18) $\mathrm{mg} \mathrm{HCN}=0.840 \mathrm{mg} / 100 \mathrm{~g}$.

\section{Estimation of phytic acid ${ }^{11}$}

About $20 \mathrm{~g}$ of dry sample were weighed and the phytic acid extracted with $0.5 \mathrm{~N} \mathrm{HCl}$ and then precipitated as ferric phytate using ferric chloride. This precipitate was converted to sodium phytate using $\mathrm{NaOH}$ and then digested with an acid mixture of equal portions of conc. $\mathrm{H}_{2} \mathrm{SO}_{4}$ and $65 \% \mathrm{HClO}_{4}$. The liberated phosphorus was quantified calorimetrically at $620 \mathrm{~nm}$ with Spectronic 20 spectrometer model using molybdate solution for colour development.

\section{Estimation of oxalate ${ }^{12}$}

$2.0 \mathrm{~g}$ of Dry sample were digested with $6 \mathrm{~N}$ diluted $\mathrm{HCl}$ and the oxalate precipitated within $\mathrm{CaCl}_{2}$ as calcium oxalate. The precipitated oxalate was washed with $25 \%$ sulphuric acid and dissolved in hot water before titrating against $0.05 \mathrm{~N}$ potassium permanganate to determine its concentration. Oxalate was quantified by equating $1 \mathrm{~mL}$ of $0.05 \mathrm{~N} \mathrm{KMnO}_{4}$ to $2.2 \mathrm{mg}$ oxalate.

\section{Preparation of cocoyam flour}

The cocoyam flour was prepared by peeling and slicing the corms and cormels and then washing the slices thoroughly in water so as to remove as much mucilaginous material as possible. After washing, the slices are left soaked in water overnight, then rewashed and finally immersed for $3 \mathrm{~h}$ in $0.25 \%$ bisulphite solution. They were blanched in boiling water for 4-5 min, drained and dried, preferably in oven at $57-60{ }^{\circ} \mathrm{C}$. The dried slices were ground, sieved to 40-50 mesh and stored.

\section{Bread making}

The straight dough method was used in the baking operation. This involves the mixing of the paste (cocoyam, wheat and the composite flour) with other ingredients namely sugar $(6 \%)$, fat $(3 \%)$, baking powder $(1.5 \%)$, yeast $(1 \%)$ and water. This is closely followed by kneading process which ensures better crumb quality of the bread. After the kneading, the dough is cut into the required weights and molded into the pans, allowed to rest and then leavened by the yeast in a warm room. This is called fermentation stage which determines good or poor rising of the dough. With good formulation, mixing, kneading and favourable condition at the fermentation/proofing stage, the loaves surely turn out good at the baking stage. The dough at the fermentation stage is allowed for six hours and the oven temperature is set $600{ }^{\circ} \mathrm{C}$ for forty minutes before taking out the bread. 


\section{Bread evaluation}

All the baked bread was evaluated using a panel of judges consisting of 20 people. A 9-point hedonic scale as recommended by Amerine et al ${ }^{13}$ was used for the assessment to evaluate the colour, texture, taste, flavour and over all acceptability of products. In this scale, 1 represents most disliked while 9 represents most liked for the evaluation of taste, texture, flavour, colour and overall acceptability.

\section{Results and Discussion}

The result of the proximate, mineral, vitamins and toxicant composition, of cocoyam is as shown in Table 1-4. Table 5 shows the physical quality of the bread produced from Colocasia species of cocoyam while Table 6 shows the result of the sensory evaluation test carried out on the bread samples. The mean proximate composition of the produced bread samples are shown in Table 7.

Table 1. Proximate composition of cocoyam

\begin{tabular}{clc}
\hline Parameter & Xanthosoma sagittifolium & Colocasia esculenta \\
\hline Moisture (\% wet weight) & $68.28 \pm 3.59$ & $70.67 \pm 4.65$ \\
Ash (\% dry mass) & $1.10 \pm 0.15$ & $0.83 \pm 0.17$ \\
Crude protein (\% dry mass) & $1.56 \pm 0.33$ & $1.36 \pm 0.35$ \\
Crude fat (\% dry mass) & $1.40 \pm 0.20$ & $1.10 \pm 0.00$ \\
Crude fibre (\% dry mass) & $0.82 \pm 0.20$ & $1.39 \pm 0.11$ \\
Carbohydrate (\% dry mass) & $41.89 \pm 5.00$ & $32.73 \pm 4.33$ \\
Energy value (cal/100 g) & 186.40 & 146.26 \\
\hline
\end{tabular}

Table 2. Mineral element composition of cocoyam

\begin{tabular}{ccc}
\hline Element, $\mathrm{mg} / 100 \mathrm{~g}$ & Xanthosoma sagittifolium & Colocasia esculenta \\
\hline Zinc & $10.523 \pm 0.478$ & $2.120 \pm 2.000 \mathrm{E}-02$ \\
Manganese & $5.830 \pm 0.110$ & $0.249 \pm 4.619 \mathrm{E}-03$ \\
Nickel & $0.813 \pm 2.516 \mathrm{E}-02$ & $0.756 \pm 2.425 \mathrm{E}-02$ \\
Copper & $0.235 \pm 1.155 \mathrm{E}-03$ & $0.877 \pm 4.619 \mathrm{E}-03$ \\
Iron & $1.391 \pm 1.847 \mathrm{E}-02$ & $1.011 \pm 2.501 \mathrm{E}-02$ \\
Sodium & $20.200 \pm 0.000$ & $24.147 \pm 0.129$ \\
Potassium & $580.483 \pm 5.773 \mathrm{E}-03$ & $500.510 \pm 0.108$ \\
Lead & $0.608 \pm 1.200 \mathrm{E}-02$ & $1.0133 \pm 3.075 \mathrm{E}-02$ \\
Calcium & $47.733 \pm 2.157$ & $13.953 \pm 2.355$ \\
Cadmium & $25.680 \pm 0.1150$ & $47.243 \pm 0.002$ \\
Magnesium & $63.240 \pm 0.130$ & $51.414 \pm 3.536 \mathrm{E}-03$ \\
Phosphorus & & \\
\hline
\end{tabular}

Table 3. Vitamin composition of cocoyam

\begin{tabular}{clc}
\hline Parameter $(\mathrm{mg} / 100 \mathrm{~g})$ & Xanthosoma sagittifolium & Colocasia esculenta \\
\hline Vitamin C & $23.823 \pm 0.2815$ & $26.930 \pm 3.000 \mathrm{E}-02$ \\
$\beta$-Carotene & $6.823 \pm 0.1620$ & $11.066 \pm 0.1002$ \\
\hline
\end{tabular}

Table 4. Toxicant composition of cocoyam

\begin{tabular}{ccc}
\hline Toxicant $(\mathrm{mg} / 100 \mathrm{~g})$ & Xanthosoma sagittifolium & Colocasia esculenta \\
\hline Oxalate & $0.400 \pm 0.000$ & $5.010 \pm 0.021$ \\
Hydrocyanic acid & $1.570 \pm 0.013$ & $3.330 \pm 0.200$ \\
Phytic acid & $71.310 \pm 1.100$ & $88.210 \pm 1.530$ \\
\hline
\end{tabular}


Table 5. Physical quality of Colocasia esculenta flour bread

\begin{tabular}{|c|c|c|c|c|c|c|c|c|c|}
\hline \multicolumn{2}{|l|}{ Sample } & $\mathrm{I}$ & \multicolumn{2}{|r|}{$\mathrm{A}$} & \multicolumn{2}{|l|}{$\mathrm{B}$} & $\mathrm{C}$ & \multicolumn{2}{|r|}{$\mathrm{G}$} \\
\hline \multicolumn{2}{|l|}{$\%$ Wheat } & 100 & \multicolumn{2}{|r|}{80} & \multicolumn{2}{|l|}{70} & 50 & \multicolumn{2}{|r|}{0} \\
\hline \multicolumn{2}{|l|}{$\%$ Colocasia } & 0 & \multicolumn{2}{|r|}{20} & \multicolumn{2}{|c|}{30} & 50 & \multicolumn{2}{|c|}{100} \\
\hline \multicolumn{2}{|l|}{ Loaf weight, $\mathrm{g}$} & 183.43 & \multicolumn{2}{|c|}{137.17} & \multicolumn{2}{|c|}{165.18} & 170.15 & \multicolumn{2}{|c|}{149.54} \\
\hline \multicolumn{2}{|c|}{ Loaf volume, $\mathrm{cm}^{3}$} & 649.39 & \multicolumn{2}{|c|}{430.90} & \multicolumn{2}{|c|}{498.22} & 450.14 & \multicolumn{2}{|c|}{385.16} \\
\hline \multicolumn{2}{|c|}{ Specific volume, $\mathrm{cm}^{3} / \mathrm{g}$} & 3.54 & \multicolumn{2}{|c|}{3.14} & \multicolumn{2}{|c|}{3.02} & 2.65 & \multicolumn{2}{|c|}{2.58} \\
\hline \multicolumn{10}{|c|}{ Table 6. Sensory evaluation of bread loaves } \\
\hline \multirow[b]{2}{*}{ Parameters } & \multicolumn{4}{|c|}{ Colocasia esculenta } & \multicolumn{5}{|c|}{ Xanthosoma sagittifolium } \\
\hline & $\begin{array}{c}\text { A } \\
20 \%\end{array}$ & $\begin{array}{c}\text { B } \\
30 \%\end{array}$ & $\begin{array}{c}C \\
50 \%\end{array}$ & $\begin{array}{c}\mathrm{G} \\
100 \%\end{array}$ & $\begin{array}{c}\text { D } \\
20 \%\end{array}$ & $\begin{array}{c}\mathrm{E} \\
30 \%\end{array}$ & $\begin{array}{c}\mathrm{F} \\
50 \%\end{array}$ & $\begin{array}{c}\mathrm{H} \\
100 \%\end{array}$ & $\begin{array}{c}\mathrm{I} \\
100 \%\end{array}$ \\
\hline Colour & 6.6 & 6.4 & 7.5 & 5.6 & 5.3 & 6.4 & 7.8 & 3.7 & 8.4 \\
\hline Taste & 5.0 & 4.0 & 4.6 & 5.6 & 6.3 & 6.8 & 4.5 & 3.3 & 7.7 \\
\hline Flavour & 3.6 & 5.1 & 4.3 & 4.0 & 6.5 & 5.1 & 4.9 & 3.7 & 7.6 \\
\hline Texture & 5.1 & 5.0 & 5.7 & 4.6 & 7.9 & 6.8 & 7.3 & 4.8 & 7.3 \\
\hline Overall acceptability & 5.3 & 4.8 & 4.2 & 4.1 & 6.6 & 5.6 & 5.1 & 4.8 & 8.2 \\
\hline
\end{tabular}

Table 7. Mean proximate composition of the bread samples

\begin{tabular}{cccc}
\hline Parameters & $\begin{array}{c}\text { Colocasia } \\
\text { esculenta }\end{array}$ & $\begin{array}{c}\text { Xanthosoma } \\
\text { sagittifolium }\end{array}$ & Wheat bread \\
\hline Moisture (\% wet weight) & $15.0633 \pm 1.4531$ & $12.1133 \pm 1.5975$ & $11.2867 \pm 0.7978$ \\
Ash (\% dry mass) & $31.4367 \pm 1.6159$ & $20.3233 \pm 1.0446$ & $21.1633 \pm 2.3139$ \\
Crude protein & $19.3067 \pm 0.7129$ & $20.2033 \pm 1.3335$ & $20.6033 \pm 0.8113$ \\
Crude fat (\% dry mass) & $10.7367 \pm 0.4099$ & $12.2967 \pm 0.8914$ & $8.3633 \pm 0.4104$ \\
Crude fibre (\% dry mass) & $2.8733 \pm 0.6294$ & $3.4767 \pm 0.5450$ & $1.7000 \pm 0.1229$ \\
Carbohydrate, \% & $39.6733 \pm 1.3070$ & $45.0133 \pm 3.0274$ & $37.8033 \pm 0.3782$ \\
Energy value & 332.5503 & 371.536 & 308.891 \\
(calories/100 g) & & & \\
\hline
\end{tabular}

Cocoyam, like other root crops has high water content. Colocasia esculenta had higher moisture content $(70.67 \pm 4.65 \%$ wet weight) compared to Xanthosoma sagittifolium with $68.28 \pm 3.59 \%$. The result of this analysis agreed with the previous work of bradbury ${ }^{6}$, which showed Colocasia esculenta to have $69.2 \%$ while Xanthosoma sagittifolium had $67.71 \%$. However, this figure differs slightly with some previous report which showed Xanthosoma sagittifolium to have $70-77 \%$ while Colocasia esculenta has about $73-78 \%$ moisture. The values of moisture content recorded for the various species explains the texture and shelf life features. Xanthosoma sagittifolium with less water content keeps longer than the Colocasia esculenta which contains relatively high amount of moisture. So many factors including environmental conditions, age and time of harvest of the samples affect the moisture content of tuber crops. Some of these factors might have contributed to the difference between the measured moisture content and values reported by some other authors.

The values obtained for each ash in the two cocoyam varieties considered in this supports the findings of Nwanekezi et al ${ }^{6}$. Xanthosoma sagittifolium recorded ash value of $1.1 \pm 0.15 \%$ while Colocasia esculenta recorded $0.83 \pm 0.17 \%$. Bradbury ${ }^{6}$ in their work recorded the ash content for Xanthosoma sagittifolium as $1.04 \%$ while that of Colocasia esculenta was $0.87 \%$. There is a direct proportionality between ash content and mineral element composition and the result obtained were consistent with this trend ${ }^{1}$. 
According to Sinful and Darko ${ }^{14}$, roots and tubers are estimated to contain about $8 \%$ of protein. Ciacco et $a l^{5}$ also stated that among the root crops, cocoyam shows better performance in terms of protein. However, the result of the analysis showed that the protein content of Xanthosoma sagittifolium $(1.56 \pm 0.33 \%)$ is higher than that of Colocasia esculenta $(1.36 \pm 0.35 \%)$. These results are at variance with values of 4.64 and $5.08 \%$ reported by Nwanekezi et al. ${ }^{6}$ for Xanthosoma sagittifolium and Colocasia esculenta respectively.

Nutritionally, with a recommended allowance of 23-36 g in children and 44-56 g for adults (Nutritional Research Council ${ }^{15}$ ), cocoyam seem to be a poor source of protein and dependence on it will give rise to protein-energy malnutrition (PEM), with kwashiorkor and marasmus threatening the children $\left(\mathrm{FAO}^{16}\right)$. The protein in cocoyam especially Colocasia esculenta are rich with essential amino acids, relatively low only in histidine and lysine $\left(\mathrm{FAO} / \mathrm{WHO}^{17}\right)$. Protein deficiency causes delayed bone healing and depresses fibroblast repairs and callus formation.

The fat contents of the cocoyam species $(1.4 \pm 0.2 \%$ and $1.1 \pm 0.01 \%$ for Xanthosoma and Colocasia respectively) used in the study were relatively higher than values of 0.88 and $0.83 \%$ reported by Nwanekezi et al. ${ }^{6}$ for Xanthosoma and Colocasia respectively, it can be deduced that cocoyam is not an excellent source of fat.

High fat intake and obesity appear to relate to the incidence of cancer of the breast, colon and ovary, increasing disease risk by influencing turn over behaviour than actually being causative ${ }^{11}$. This makes cocoyam with its relatively low fat content recommendable for obese patients. Fats stabilize cholesterol solubility in blood as well as provide high energy on combustion.

Perssini and Sensidoni ${ }^{19}$ observed that there is a relatively low yield of dietary fibre in cocoyam. Values that ranged between $0.6-1.9 \%$ for Xanthosoma specie and between 0.4-2.9\% for the Colocasia specie was reported. The result of this work shows that the fibre content of Xanthosoma specie $(0.82 \pm 0.2 \%)$ is lower than the fibre content of the Colocasia specie $(1.39 \pm .01 \%)$. This result agrees compares favourably with values $(0.36 \%$ and $0.20 \%$ reported by Nwanekezi et al. ${ }^{6}$ for Xanthosoma and Colocasia respectively.

Fibre has physical properties that have the potential of binding fats, cholesterol and minerals such as zinc, copper, Iron and magnesium. A fibre intake in excess of 30-40 g/day means a great loss of these important nutrients ${ }^{20}$. Also symptomless diverticulae, affecting mainly the distal colon is caused by prolonged consumption of diets low in fibre. Fibre, with its bulking properties, is useful in treating irritable bowel syndrome (IBS). Available literature shows that high fibre diets reduce the amount of protein and energy absorbed from food ingested ${ }^{2,18}$.

Of the solid nutrient content in roots and tuber crops, carbohydrates predominate ${ }^{2}$. The two cocoyam varieties used for this work have carbohydrate content of $41.89 \%$ and $32.73 \%$ for the Xanthosoma and the Colocasia species respectively. These values are lower than the values of $84.2 \%$ and $84.1 \%$ for Xanthosoma and Colocasia respectively ${ }^{6}$.

The samples showed relatively high potassium content. The values obtained were $580.483 \pm 5.773 \mathrm{E}-03 \mathrm{mg} / 100 \mathrm{~g}$ and $500.510 \pm 0.108 \mathrm{mg} / 100 \mathrm{~g}$ for both Xanthosoma and Colocasia respectively. Potassium is a determinant of anion-cation balance in the cell, it also activate numerous enzymes. It is useful for the formation of glycogen, protein and for the maintenance of osmotic pressure ${ }^{18}$. The deficiency of potassium has been implicated in the etiology of oedema and increased risk of arrythmia. High potassium diets have been found to 
be useful in treating hypertension. Potassium is thought to lower blood pressure by lowering the remin-angiotennin receptor levels ${ }^{11}$. The recommended daily requirement of $350 \mathrm{mg}$ in infants and $562 \mathrm{mg}$ in adults ${ }^{15}$ makes cocoyam a fairly adequate source of potassium. Potassium salt has been found to be a better substitute for sodium salt because it exerts less effect on the blood sugar compare to sodium salt. Consequently, high potassium salt intake and low sodium salt intake is recommended for a diabetic patient. Therefore cocoyam is a good source of diet for diabetic patient.

The result for the calcium content of Xanthosoma and Colocasia species obtained were $47.733 \pm 2.157 \mathrm{mg} / 100 \mathrm{~g}$ and $13.953 \pm 2.355 \mathrm{mg} / 100 \mathrm{~g}$ respectively. This result show higher values than what was obtained by Nwanekezi et al. ${ }^{6}$. The recommended daily allowance by national research council ${ }^{5}$ is between $360-1200 \mathrm{mg} / 100 \mathrm{~g}$. The growing child requires considerably more of calcium than adult. The cocoyam species may serve as good dietary source of calcium for infants. The availability of this mineral can be limited by the presence of anti-nutrients as oxalates and phytates.

The result obtained for the concentration of iron in Xanthosoma and Colocasia were $1.391 \pm 1.847 \mathrm{E}-02 \mathrm{mg} / 100 \mathrm{~g}$ and $1.011 \pm 2.501 \mathrm{E}-02 \mathrm{mg} / 100 \mathrm{~g}$ respectively. There was no significant difference between the two species. Cocoyam species used for this work were actually low in iron compared with the recommended daily intake of $10-18 \mathrm{mg}$ by national research council ${ }^{15}$ and 5-28 mg by $\mathrm{FAO} / \mathrm{WHO}^{17}$. Cocoyam would therefore be considered a good source of iron. Its availability would depend on the presence of other dietary factors enhancing its absorption such as cystein and ascorbate (reductants), or inhibiting it as phytic acid. Complications leading to anaemia in man occur in low iron intake. Anaemia is a state of iron depletion resulting in low haemoglobin. Infants' store of iron is low as milk is low in iron and supplement with about $7 \mathrm{mg}$ of iron per day to maintain infants iron store has been recommended $^{21}$.

The concentration of zinc for the two species of cocoyam was $10.523 \pm 0.478 \mathrm{mg} / 100$ $\mathrm{g}$ and $2.120 \pm 2.000 \mathrm{E}-02 \mathrm{mg} / 100 \mathrm{~g}$ for Xanthosoma and Colocasia species respectively. Comparing these values with the recommended $10.15 \mathrm{mg}$ daily intake of zinc by national research council ${ }^{15}$, it can be deduced that Xanthosoma would serve as a good source of zinc. Zinc is needed for normal growth and development of all living cells as it helps in protein metabolism (as component of carboxypeptidase) and as component of carbonic anhydrase. Zinc has also been found helpful in slain disorders such as burns and surgical wounds ${ }^{20,22}$.

The concentration of magnesium obtained for Xanthosoma and Colocasia were $25.680 \pm 0.115 \mathrm{mg} / 100 \mathrm{~g}$ and $47.243 \pm 0.002 \mathrm{mg} / 100 \mathrm{~g}$ respectively. Magnesium is involved in ATP-ADP catalysis and conduction of nerve impulse and is known to promote muscle relaxation. It is involved in the activation of many enzymes in the body ${ }^{23}$. With a recommended daily allowance of $50 \mathrm{mg}$ for infants and $350 \mathrm{mg}$ for adults ${ }^{15}$, cocoyam diets alone (unsupplemented) are not adequate source of magnesium.

The concentration of sodium obtained were $20.200 \pm 0.000 \mathrm{mg} / 100 \mathrm{~g}$ and $24.147 \pm 0.129 \mathrm{mg} / 100 \mathrm{~g}$ for Xanthosoma and Colocasia species respectively. Sodium is important in the maintenance of a constant environment for the living cells especially in nerves, muscles and sensory cells when they are involved in transmission of impulses. They are found in extra cellular fluid portion. The low sodium content of cocoyam compare to those of other tubers also makes these two species of cocoyam to be a recommended diet for diabetic patient. 
The value obtained for phosphorus content were $63.240 \pm 0.130 \mathrm{mg} / 100 \mathrm{~g}$ and $51.414 \pm 3.536 \mathrm{E}-03 \mathrm{mg} / 100 \mathrm{~g}$ for both Xanthosoma and Colocasia respectively. These levels of phosphorus are above the recommended daily requirement of $0.6-1.5 \mathrm{~g}$ phosphorus ${ }^{24}$. As a dietary phosphate deficiency is relatively rare due to the efficient absorption of phosphate (50-90\%), food value up to $300 \mathrm{mg}$ can be used efficiently in metabolic process. About $85 \%$ of the body phosphate occurs in bone ${ }^{21}$. Phosphorus involvement in cellular reactions as phosphate esters is an essential step in the metabolism of carbohydrates as well as being a source of energy in the form of ATP in cells and creating phosphate in muscles.

Other elements considered were manganese, nickel, copper, lead and cadmium for the two species. The results obtained were $5.830 \pm 0.110 \mathrm{mg} / 100 \mathrm{~g}$ and $0.249 \pm 4.619 \mathrm{E}-03 \mathrm{mg} / 100 \mathrm{~g}$, $0.813 \pm 2.516 \mathrm{E}-02 \mathrm{mg} / 100 \mathrm{~g}$ and $0.756 \pm 2.425 \mathrm{E}-02 \mathrm{mg} / 100 \mathrm{~g}, 0.235 \pm 1.155 \mathrm{E}-03 \mathrm{mg} / 100 \mathrm{~g}$ and $0.877 \pm 4.619 \mathrm{E}-03 \mathrm{mg} / 100 \mathrm{~g}, 0.608 \pm 1.200 \mathrm{E}-02 \mathrm{mg} / 100 \mathrm{~g}$ and $1.0133 \pm 3.075 \mathrm{E}-02 \mathrm{mg} / 100 \mathrm{~g}$, 0.00 and $0.00 \mathrm{mg} / 100 \mathrm{~g}$ for Xanthosoma and Colocasia respectively. This result indicates that there is a reasonable concentration of manganese in Xanthosoma whereas other elements exist in trace quantities.

The value obtained for the vitamin C content for Xanthosoma and Colocasia were $23.823 \pm 0.2815 \mathrm{mg} / 100 \mathrm{~g}$ and $26.930 \pm 3.00 \mathrm{E}-02 \mathrm{mg} / 100 \mathrm{~g}$ respectively. The values obtained were higher than those recorded by parkinson ${ }^{25}$. The daily requirements for vitamin $\mathrm{C}$ have been given as $35 \mathrm{mg}$ for infants and $60 \mathrm{mg}$ for adults ${ }^{15}$. This means that cocoyam is an adequate source for the supply of dietary vitamin $\mathrm{C}$ since an adult consuming $500 \mathrm{~g}$ of cocoyam can afford the aversion of the symptoms and disorders of ascorbic acid deficiency.

The concentration of $\beta$-Carotene content in Xanthosoma and Colocasia were found to be $6.823 \pm 0.1620 \mathrm{mg} / 100 \mathrm{~g}$ and $11.0667 \pm 0.1002 \mathrm{mg} / 100 \mathrm{~g}$ respectively. $\beta$-carotene is widely used as the vitamin A precursor since it is metabolically oxidized to retinol (vitamin A.) in animals except cat. It is also used as effective sunscreen agent in erythropoietic protoporphyria. Perhaps, the most important useful available carotenoids are $\beta$-carotene and lycopene, which are found richly in carrot and tomato respectively. These carotenoids are used in industries for the safe colouration of foods as exemplified in the colouring and fortification of margarine and poultry feedstuff ${ }^{20}$.

The result obtained for the total oxalate for Colocasia and xanthosoma were $5.01 \pm 0.21 \mathrm{mg} / 100 \mathrm{~g}$ and $0.40 \pm 0.00 \mathrm{mg} / 100 \mathrm{~g}$ respectively. All roots and tubers contain oxalate as calcium oxalate and soluble oxalate ${ }^{26}$. The oxalates have been implicated as mechanical defense mechanism, storage reserves and stores of excess calcium ${ }^{22}$.

Consumption of large doses of oxalic acid causes corrosive gastroenteritis, shock, convulsive symptoms, low plasma calcium, high plasma oxalates and renal damage ${ }^{27,28}$. Oxalate binds with calcium and prevents its absorption in the alimentary canal. The oxalate bound calcium from other foods to give calcium oxalate which is excreted in the faeces ${ }^{29}$. While cows, sheep and goats can utilize calcium oxalate, it is only poorly utilized by man. The amount of soluble oxalate in tubers is comparatively small. The peels of tubers contain more oxalate than the peeled tubers; thus supporting the role of oxalate as allelochemicals. The lethal dose for soluble oxalate is $2-5 \mathrm{~g}$ giving cocoyam a safe margin ${ }^{29}$. No incidence of oxalic acid poisoning has been reported in Nigeria ${ }^{26}$.

The result in the antinutrient composition shows a low content of hydrocyanic acid in both Colocasia and xanthosoma. The values (in \%) were $3.330 \pm 0.200 \mathrm{mg} / 100 \mathrm{~g}$ and $1.870 \pm 0.13 \mathrm{mg} / 100 \mathrm{~g}$ for both Colocasia and xanthosoma respectively. The lethal dose of cyanide 
was reported to be $35.0 \mathrm{mg}^{29}$. This gives cocoyam a safe margin. Goesaert et al. ${ }^{29}$ reported that hydrocyanic acid exert inhibitory effect at the cytochrome oxidase level in the electron transport chain.

The results obtained for phytic acid concentration were found to be $88.210 \pm 1.530 \mathrm{mg} / 100 \mathrm{~g}$ and $71.310 \pm 1.100 \mathrm{mg} / 100 \mathrm{~g}$ for Colocasia and Xanthosoma respectively. Phytates like oxalate are known to limit the availability of calcium, magnesium, iron and phosphorus by formation of insoluble compounds or salts with the minerals. Humans lack the enzyme phytase to hydrolyse the phytate group to release calcium. The inhibitory effect of phytic acid is only a practical problem when calcium food is consumed with food high in phytic acid.

It has been found that foods/food materials having phytic acid concentration greater than $19 \mathrm{mg} / 100 \mathrm{~g}$ showed low iron diffusibility ${ }^{30}$. However, the observations from this work showed that Xanthosoma was rather lower in phytate content than Colocasia and even richer in vitamin $\mathrm{C}$ (ascorbate) which enhances bivalent iron absorption, thus rendering some inconsistency with the earlier chains.

The result of the physical quality characteristics of bread baked from the different cocoyam varieties at various substitution levels is shown in Table 5. The best bread in terms of loaf weight, loaf volume and specific volume was given by sample I (control), containing $100 \%$ wheat flour with a specific volume of $3.54 \mathrm{~cm}^{3} / \mathrm{g}$. This was closely followed by sample A containing 20\% substitution level of Colocasia variety with specific volume of $3.25 \mathrm{~cm}^{3} / \mathrm{g}$; then sample D which has $20 \%$ substitution level of Xanthosoma variety with specific volume of $3.14 \mathrm{~cm}^{3} / \mathrm{g}$. This was closely followed by sample B which has $30 \%$ substitution level of Colocasia variety with specific volume of $3.10 \mathrm{~cm}^{3} / \mathrm{g}$ and finally sample E containing $30 \%$ substitution level of Xanthosoma variety with specific volume of $3.02 \mathrm{~cm}^{3} / \mathrm{g}$.

On the other hand, the poorest performance in terms of loaf weight, loaf volume and specific volume was given by sample $\mathrm{H}$ containing $100 \%$ of Xanthosoma with specific volume of $2.58 \mathrm{~cm}^{3} / \mathrm{g}$, followed by G, with $100 \%$ of Colocasia with specific volume of $2.62 \mathrm{~cm}^{3} / \mathrm{g}$ then sample F with $50 \%$ Xanthosoma with specific volume of $2.65 \mathrm{~cm}^{3} / \mathrm{g}$ and sample C with $50 \%$ of Colocasia with specific volume of $2.91 \mathrm{~cm}^{3} / \mathrm{g}$.

Of interest is the fact that these two varieties of cocoyam showed optimal performance in the physical quality indices of substitution of $20 \%$ and poorer performance at $100 \%$ substitution levels. Also to be noted is that amongst all the varieties, Colocasia performed best at each level of substitution, followed by Xanthosoma.

The sensory quality statistics also show that the control sample was superior in all sensory characteristics compared with the cocoyam based composite flour bread (Table 6). In terms of colour, sample (I) significantly $(\mathrm{p}<0.5)$ performed better than any of the other samples. It was noted that as the level of substitution of cocoyam varieties increased, the colour rating decreased (except for samples $\mathrm{C}$ and $\mathrm{F}$ ). The colour of samples $\mathrm{F}$ and $\mathrm{C}$ were closer to the colour of the control samples implying that in terms of colour rating, these samples are preferred. The poorest colour rating was recorded for sample $\mathrm{H}$. The poorer rating in colour of cocoyam sample as the percentage of substitution of wheat flour with grated cocoyam increased could be attributed to browning reaction in the cocoyam ${ }^{20}$. It was observed that as soon as the peeled raw cocoyams were sliced, they started darkening due to oxidation. This darkening effect is carried into the mixed dough and finally into the bread. Obviously, as more of the grated cocoyam that was added to the sample, the more intense was the darkening effect. 
In terms of taste, samples E, D, G, A trailed behind I and were regarded as being good. The strong taste, flavour and texture of cocoyam seemed to have negatively affected the cocoyam based samples and the higher the level of substitution of the wheat flours with the cocoyam, the poorer the rating of the sample irrespective of variety.

In terms of flavour, sample D was rated almost as good as sample (I), control i.e. wheat flour. Sample A was rated worst of all the samples. In terms of texture, samples D, F, E, were not significantly different $(\mathrm{p}>0.05)$. They were rated soft whereas $\mathrm{G}$ and $\mathrm{H}$ were rated hard.

The overall acceptability result indicates that the control sample was significantly more acceptable than any other bread samples. This was followed by D with $20 \%$ substitution level of Xanthosoma. Other fairly rated samples were E with $30 \%$ substitution level of Xanthosoma, sample A, F with 20\% substitution level of Colocasia and 50\% substitution level of Xanthosoma respectively. The worst sample in terms of acceptability was sample G with $100 \%$ of Colocasia.

Generally, it is worthy of note that the colour contributed greatly to the assessment of the individual samples, followed by texture, taste and flavour. On the whole, apart from sample I which was rated best, the evaluation showed that sample D with $20 \%$ substitution level of Xanthosoma was rated good followed by sample E with $30 \%$ substitution of Xanthosoma. Samples A and F wee rated as being fair. The worst in terms of performance were $\mathrm{G}$ and $\mathrm{C}$.

The proximate composition of the bread samples produced from Colocasia flour, Xanthosoma and wheat flour were also conducted and the results recorded in Table 7. The moisture content of the bread produced from Colocassia spp. (15.06\%) of cocoyam was the highest followed by that of Xanthosoma spp (12.11\%) and least for the wheat bread $(11.28 \%)$. According to Khattak et $a l^{22}$, moisture content of food could influence the shelf life of the food hence the shelf life for the different bread samples would follow the trend; wheat $>$ Xanthosoma > Colocasia, since all the bread were prepared under similar condition and the additives were essentially the same. Different food materials have different capacity for absorbing and that there could be occluded, adsorbed water in some food samples ${ }^{4}$. Some or all these factors might have been responsible for the differential moisture capacity of the different breads. As expected, the moisture content of the Xanthosoma and Colocasia bread samples were however found to be lower in the bread samples compared to the original food materials. The reduction in the moisture content might have been due to the effect of change in temperature. According to Ekop et al. ${ }^{12}$, when any food material is exposed to a temperature above $100{ }^{\circ} \mathrm{C}$, all or most of the moisture content of that food material would be reduced because the boiling point of water at standard atmospheric pressure is $100{ }^{\circ} \mathrm{C}$. There was no significant difference between the moisture content of the Xanthosoma bread and wheat bread ( $\mathrm{t}=3.369, \mathrm{n}=3, \alpha=0.05$ ) while there was a significant difference between the moisture content of Colocassia bread and wheat bread $(\mathrm{t}=15.39, \mathrm{n}=3, \alpha=0.05)$. This suggest that the Xanthosoma bread is a better substitute to wheat bread than the Colocassia bread with respect to moisture content, shelf life and other parameters that are influenced by moisture.

The total ash content of the Xanthosoma bread and that of the Colocassia bread were found to be higher than the ash content of the raw samples. This might have been due to the additives that were added to the bread prior to their production. According to Eddy ${ }^{4}$, ash content of any food is a measure of the total inorganic component of the food materials hence it can be inferred that the Colocassia bread (31.44\%) has the highest ash content compared to the Xanthosoma bread $(20.32 \%)$ and the wheat bread $(21.16 \%)$. This implies that Colocassia bread might have a greater tendency to retain minerals elements at the high temperature of the oven more than the Xanthosoma bread and the wheat bread. There was no 
significant difference between the ash content of the Colocassia bread and the wheat bread and also between the Xanthosoma bread and the wheat bread. This suggests that Colocassia bread and Xanthosoma bread might serve as a good substitute for wheat bread with reference to their ash content.

The protein content of the Xanthosoma and Colocassia bread were increased as a result of baking. The increase might have been attributed to the added additives. There was no significant difference between the protein content of the Xanthosoma bread and that of the wheat bread $(\mathrm{t}=1.26, \mathrm{n}=3, \alpha=0.05)$ and also between the wheat bread and the Colocassia bread $(\mathrm{t}=2.89, \mathrm{n}=3, \alpha=0.05)$. It can therefore be stated that Colocassia bread and Xanthosoma bread are better substitute for wheat bread with regard to their protein content. There was also an increase in the fat content of Xanthosoma and Colocassia breads. The increase might have been due to the fat content of the additives. Although the fat content of Xanthosoma bread (12.30\%) was higher that the fat content of Colocassia bread $(10.74 \%)$ and wheat bread $(8.31 \%)$, there was no significant difference between the fat content of the different breads. The percentage fat content of the three bread samples was comparable and this implies that Colocassia bread and Xanthosoma bread could also serve as a substitute for wheat bread with regard to their fat content.

The fibre content of the Xanthosoma and the Colocassia were found to be increase after baking. This might have been due to the additives that were added to the baked products. Although the fibre content of Xanthosoma bread (3.48\%) was relatively higher than the fibre content of Colocassia bread $(2.87 \%)$ and that of wheat bread $(1.70 \%)$, the insignificant difference between them suggest that Colocassia bread and the Xanthosoma bread could serve as a substitute for wheat bread.

The carbohydrate content of the baked Colocassia bread and that of Xanthosoma bread were also increased due to the additives which might have contributed to the total carbohydrate content of the different breads. Available literature shows that carbohydrate is less affected by heat and this may account for the non significant difference that was observed between the carbohydrate content of the Colocassia bread and the wheat bread and also between the carbohydrate content of the Xanthosoma bread and the wheat bread. Thus the Xanthosoma and the Colocassia satisfied the alternatives for baking bread when compared to wheat. The energy value of any food materials is related to their carbohydrate, fat and protein content ${ }^{12,20}$. Hence the insignificant difference between the energy values of the different bread samples correlates with the content of carbohydrate, fat and protein as discussed above.

\section{Conclusion}

The aim of the study was to analyze samples of Colocasia and Xanthosoma species of cocoyam for their proximate composition and to utilize the samples for the production of bread. The bread samples produced from Xanthosoma and Colocasia species of cocoyam flour were comparable to bread produced from wheat flour under the same condition except for their binding properties, weight and shelf life. Thus, cocoyam can be used for the production of bread if a suitable binder is incorporated into the product. The use of additives that can improve the shelf life of the products shall also offer a promising alternative. The carbohydrate, minerals, protein, fats and oils and vitamins composition of cocoyam bread were quite acceptable and comparable to that of wheat bread produced under similar condition. The study therefore complements the work of many researchers on cocoyam. 
This study therefore recommends that future research should be aimed toward improving the quality of bread produced from cocoyam flour. Research into the utilization of the other species of cocoyam in bread making should is encouraged.

\section{References}

1. Byerlee D and Sain G, Food Policy M, 1991, 16(1), 74-84.

2. Eddy N O, Udofia P G and Eyo D, Afr J Biotech., 2007, 6(20), 2415-2418.

3. FAO, FAO production year book, Rome: Food and Agriculture Organisation of the United Nation, 1984, 39.

$4 \quad$ Akpan E J and Umoh I B, Pak J Nutr., 2004, 3, 240-243.

5. Ciacco CF and D'Appolonia B L, Cereal Chem., 1978, 55(4), 423-435.

6. $\quad$ Eze C C and Okorji E C, Afr J Sci., 2003, 5(1), 113-116.

7. Lebot V, Champagne A, Malapa, R and Shiley D, J Agric Food Chem., 2009, 57(22), 10539-10547.

8. $\quad$ Okorie S U, Ndukwe C U and Umekwe E I, J Food Sci Technol., 2005, 39, 686-689.

9. Shittu T A, Raji A O and Sanni L O, Food Res Int., 2007, 40, 280-290.

10. American Association of Cereal Chemists (AACC), Approved method of the American Association of Cereal Chemists, 10 $0^{\text {th }}$ Ed., St Paul, MN, 2002.

11. Mclaren D S and Megnid M M, Nutrition and its disorders ( $4^{\text {th }}$ Ed.,) Churchill Livingstone, New York., 1988.

12. Ekop A S, Etuk B A and Eddy N O, J Appl Sci Envirn Mgt., 2007, 41(1), 85-89.

13. Edema M O, Sanni L O and Sanni A I, Afr J Biotechnol., 2005, 4(9), 911-918.

14. Sanful RE and Darko S, Pak J Nutrition, 2010, 9(8), 810-814.

15. Launay B, Bure J and Braden J, Cereal Chem., 1977, 54, 1042 -1048.

16 Onilude A A and Idowu, Afr J Biotechnol. 2006, 5(11), 1102-1106.

17. FAO/WHO, Requirements of ascorbic acid, Vitamin D, Vitamin B and iron. Report of the Joint FAO/WHO expert group (FAO Nutrition meeting report series 47. Rome: FAO, 1970.

18. Eddy N O and Ekop A S, E-J Chem., 2007, 4(3), 212-220.

19. Peressini D and Sensidoni A, J Cereal Sci., 2009, 49, 190-201.

20. Ojinnaka M C, Akobundu E N T and Iwe M O, Pak J Nutr., 2009, 8(5), 558-567.

21. Fox B H and Cameron A G, Food Science, Nutrition and Health $5^{\text {th }}$ Ed., Edward Arnold; A division of Hodden \& Stroughton, London., 1989.

22. Khattak S D, Appolonia B L and Banasik O J, Cereal Chem., 1974, 51, 355-363.

23. Eby G A and Eby K L, Medical Hypotheses, 2010, 74(4), 649-60.

24. Food and Nutrition Board, Bulletin of the chemical composition of root and tubers crops, FAO Rome, 1989.

25. Parkinson $\mathrm{S}$, The contribution of aroids in the nutrition of people in South Pacific In: Chandra S (Ed.,) Edible Aroids, Oxford, Clarendon Press, 1984.

26. Eka O U, Nig J Sci., 1978, 51, 41- 48.

27. Passmore R and Eastood M A, Davidson and Passmore human nutrition and dietetics ( 8 th Ed.,) Edinburgh Churchill Livingstone, 1986.

28. Kelsey J L, J Amer Chem Soc., 1985, 105-110.

29. Goesaert H, Brijs K, Veraverbeke W S, Courtin C M, Gebruers K and Delcour J A, Trends Food Sci Technol., 2005 16, 12-30.

30. Eddy N O and Udoh C L, Chem Class J, 2005, 2, 12-14. 


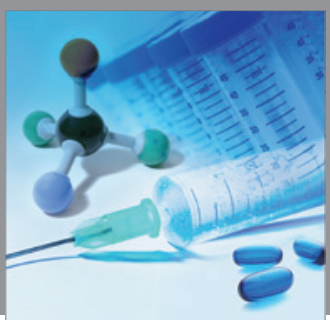

International Journal of

Medicinal Chemistry

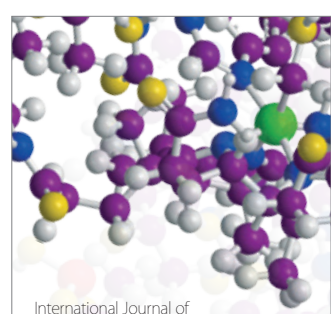

Carbohydrate Chemistry

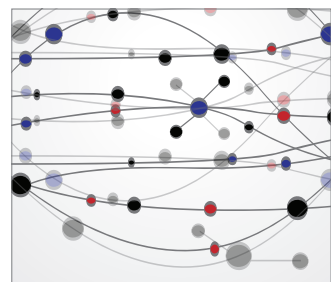

The Scientific World Journal
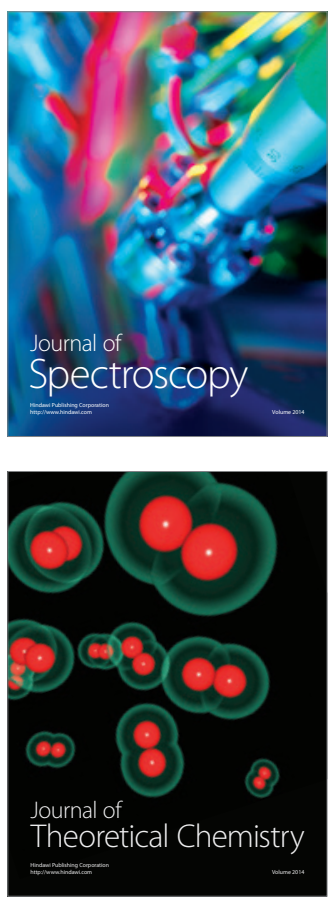
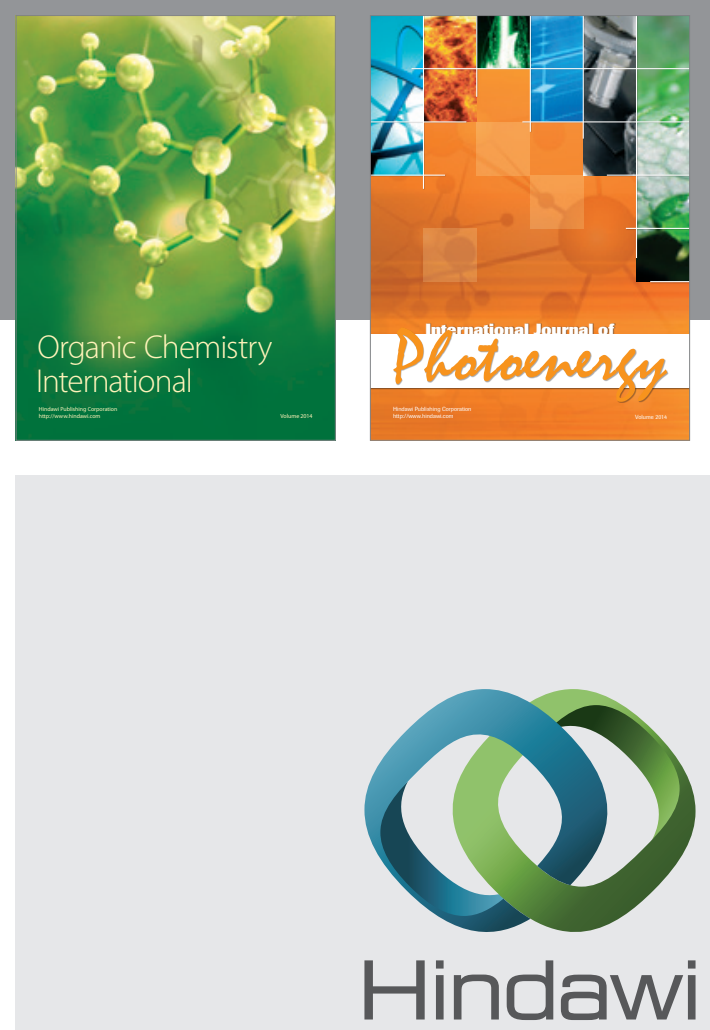

Submit your manuscripts at

http://www.hindawi.com
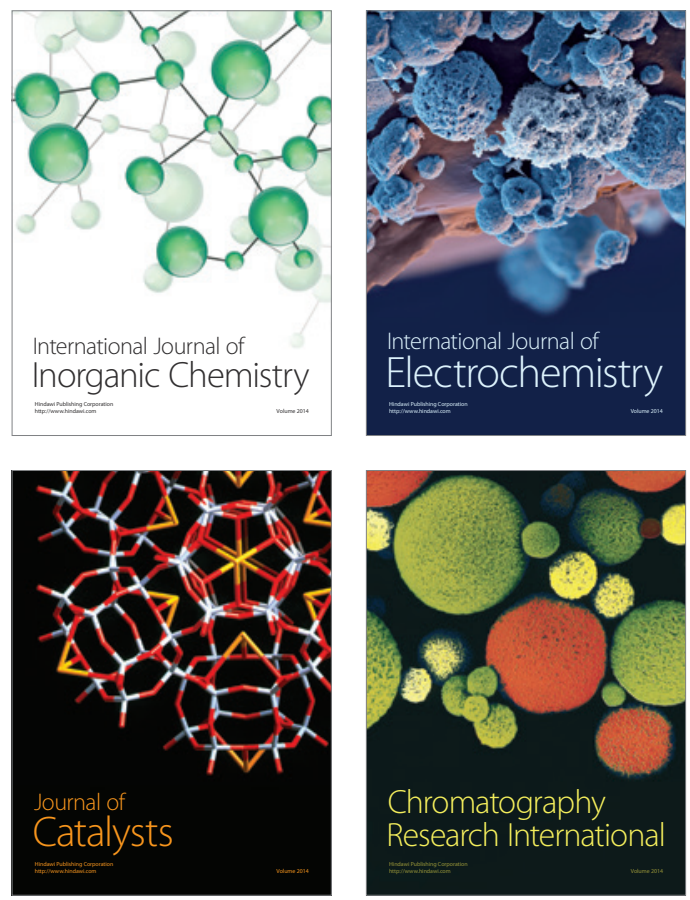
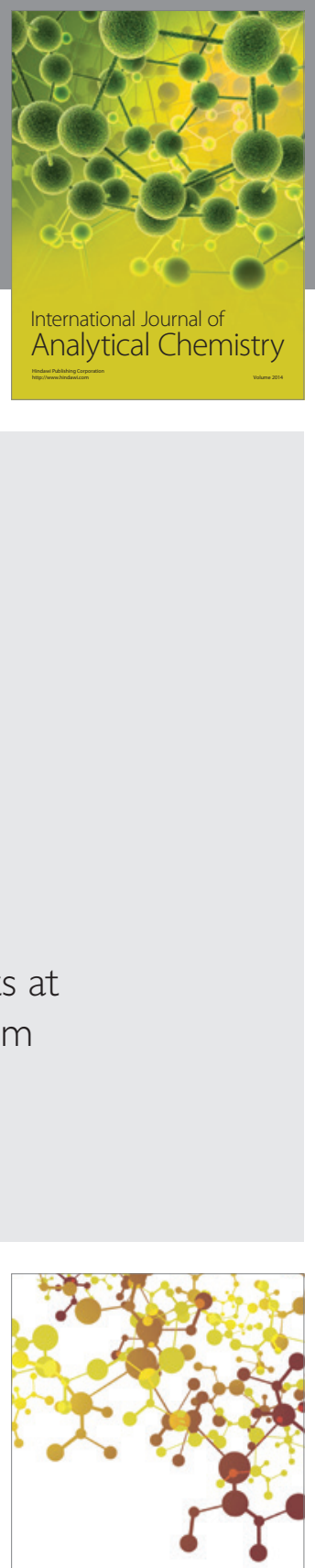

Journal of

Applied Chemistry
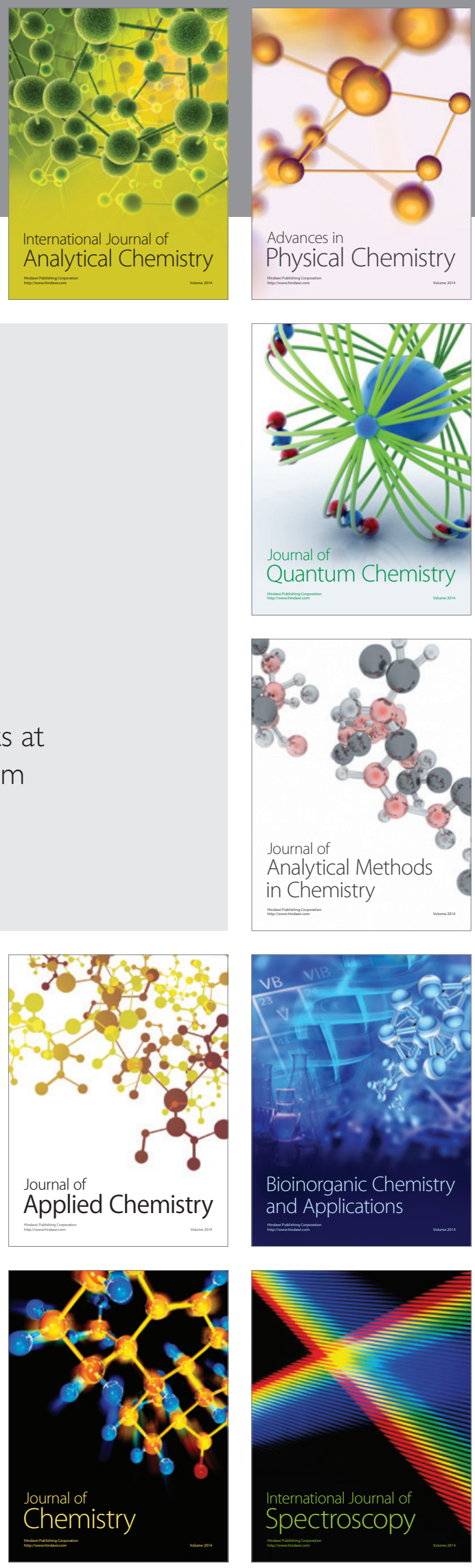